Book Review of Coming of Age in America: Transition to Adulthood in the Twenty-First Century edited by Mary C. Waters, Patrick J. Carr, Maria J. Kefalas, and Jennifer Holdaway. Berkeley and Los Angeles: University of California Press, 2011

Buchmann, M

DOI: https://doi.org/10.1086/666372

Posted at the Zurich Open Repository and Archive, University of Zurich ZORA URL: https://doi.org/10.5167/uzh-68735

Journal Article

Originally published at:

Buchmann, M (2012). Book Review of Coming of Age in America: Transition to Adulthood in the Twenty-First Century edited by Mary C. Waters, Patrick J. Carr, Maria J. Kefalas, and Jennifer Holdaway. Berkeley and Los Angeles: University of California Press, 2011. American Journal of Sociology, 118(2):517-519.

DOI: https://doi.org/10.1086/666372 


\section{CHICAGO JOURNALS}

Coming of Age in America: The Transition to Adulthood in the Twenty-First Century, edited by Mary C. Waters, Patrick J. Carr, Maria J. Kefalas, and Jennifer Holdaway Coming of Age in America: The Transition to Adulthood in the Twenty-First Century by Mary C. Waters; Patrick J. Carr; Maria J. Kefalas; Jennifer Holdaway

Review by: Marlis C. Buchmann

American Journal of Sociology, Vol. 118, No. 2 (September 2012), pp. 517-519

Published by: The University of Chicago Press

Stable URL: http://www.jstor.org/stable/10.1086/666372

Accessed: 18/12/2012 09:24

Your use of the JSTOR archive indicates your acceptance of the Terms \& Conditions of Use, available at http://www.jstor.org/page/info/about/policies/terms.jsp

JSTOR is a not-for-profit service that helps scholars, researchers, and students discover, use, and build upon a wide range of content in a trusted digital archive. We use information technology and tools to increase productivity and facilitate new forms of scholarship. For more information about JSTOR, please contact support@jstor.org. 
women's work pathways illuminates two clear mechanisms for facilitating women's steady employment: creating and providing access to better jobs and encouraging men to become equal partners in paid and unpaid labor.

Damaske begins and ends her book by discussing how women's belief systems influence their work and family lives. Women's expectations about their own employment trajectories were intertwined with their beliefs about work and family. Gendered cultural imperatives framed the way that almost every participant explained her employment decisions. This important book emphasizes the need to investigate how gendered beliefs are developed, maintained, and modified over the life course in tandem with and in response to the organization of work. The organization of work, based largely on cultural expectations about gender and social class, can become more supportive of all workers' success, as individual beliefs, interactional expectations, and cultural norms around equality constitute a nonrecursive social system. Scholars of work, family, gender, culture, and inequality will find For the Family? How Class and Gender Shape Women's Work a book worth reading, citing, and integrating into our thinking for years to come.

Coming of Age in America: The Transition to Adulthood in the TwentyFirst Century. Edited by Mary C. Waters, Patrick J. Carr, Maria J. Kefalas, and Jennifer Holdaway. Berkeley and Los Angeles: University of California Press, 2011. Pp. $\mathrm{x}+242 . \$ 24.95$ (paper).

Marlis C. Buchmann

University of Zurich

The shifting contours of the transition to adulthood in the Western world have been subject to much research over the last decades. Not only has the transition period been dramatically prolonged, but the pathways have also become more diverse. This general trend notwithstanding, comparative research has also revealed great diversity in the transition patterns within and across countries.

Mary C. Waters and colleagues' Coming of Age in America starts from these well-established facts to investigate how young people in various places in the United States experience this transition period and to discover the ways in which they attach meaning to the different steps in becoming adult. This focus is well taken, as our knowledge about how young people cope with the opportunities and constraints they encounter in their local context and interpret their pathways from adolescence to adulthood is very limited. The protagonists in this book are, indeed, the young, telling their stories about how to become adults.

To gain insight into the interplay of local context and subjective experience in the transition to adulthood, four sites have been selected: New York City, San Diego, a little town named Ellis in Iowa, and St. Paul, 
Minnesota. A total of 437 in-depth interviews with 21- to 38-year-old men and women were conducted between March 2002 and February 2003, focusing on the life history and the subjective meaning young people attach to events, choices, and outcomes in the transition process. Each case study is based on a large survey already in place, allowing purposive sampling for the inclusion of a wide variety of trajectories and transition experiences.

The edited book comprises six chapters. Chapter 1, written by Patrick J. Carr and Maria J. Kefalas, recounts the transition experiences of 104 young people who grew up in rural Iowa, in the 2,000-person town of Ellis - some respondents out of high school for 10 years (the mature transition group) and the others five years out (the recent transition group). The authors selected respondents from a 2002 survey of all incoming freshmen of Ellis High School in the years 1986-88 and 1991-93. This procedure permitted them to capture the voices not only of those who decided to stay in Ellis, but also of those who left. In view of the limited economic opportunities in this rural town, the chapter convincingly demonstrates that the pathways to adulthood are indeed predominantly shaped by whether young people stay in, return to, or leave Ellis.

In chapter 2, Teresa Toguchi Swartz, Douglas Hartmann, and Jeylan T. Mortimer focus on three highly diverse groups of young people living in St. Paul, Minnesota, a midsized city with generally good employment prospects and where people are said to believe in a strong work ethic. The Youth Development Study (YDS), targeting youths who started high school in St. Paul in 1988, offered the possibility of selecting 24 young people adhering to different patterns of career decision making, 20 poor women receiving AFDC support, and 10 men and women from the Hmong community. Despite living in the same city, the stories told provide proof of the widely differing experiences regarding work and family trajectories, civic participation, and collective identification.

Jennifer Holdaway's chapter on New York City draws on the Immigrant Second Generation in Metropolitan New York (ISGMNY) study to select a subsample from a large variety of racial and ethnic backgrounds, supplemented by interviews with native-born whites and African-Americans $(N=130)$. The 22 - to 36 -year-old respondents' stories reveal that a major force shaping the contours of the transition to adulthood in this city is the housing market, which makes it extremely difficult to get a place of their own. Living in their parents' home at an age when most other young people in the United States have left long ago thus assumes a different meaning. The external constraints downplay the importance of the transition to independent living as an essential marker of becoming adult. Nevertheless, living at home is interpreted in quite different ways, largely dependent on the young people's ethnic and socioeconomic background.

In the San Diego chapter, Linda Borgen and Rubén G. Rumbaut use a representative subsample $(N=134)$ of the third survey wave of the 
Children of Immigrants Longitudinal Study (CILS). These second-generation young people, then ages 23-27, come from a wide range of Latin American and Asian backgrounds. With education being an ever more powerful force in shaping the transition to adulthood, the authors examine the various educational pathways these young people follow and track the experiences, worries, and hopes associated with them. As $83 \%$ of the original sample, when in high school, expected to go to college because they considered higher education to be a vehicle of social mobility, the authors identified four patterns of congruence between college expectations in high school and outcomes in young adulthood: motivated achievers, optimistic strivers, wishful thinkers, and uncertain achievers.

In chapter 5, Richard A. Settersten, Jr., compares the meanings and markers of becoming adult across the four sites. Unearthing similarities and differences, the author maintains that, in the eyes of the overwhelming majority of young people, becoming adult is a long and varied process, profoundly shaped by local opportunities and constraints. In young people's subjective understanding, age norms still provide guidelines, and traditional markers of adulthood still act as "guard railings"; nevertheless, the script for adulthood has become less rigid. While this change provides a higher degree of freedom in becoming adult on the one hand, it is associated, on the other, with growing uncertainty, and successful handling of this is largely dependent on the young person's socioeconomic and ethnic background. In the concluding chapter 6, Kefalas and Carr highlight the challenges that the changing contours of the transition to adulthood pose to society at large, as well as to young people themselves caught up in this process, and suggest directions for future research.

The great merit of Coming of Age in America is in showing how young people from a wide range of social and ethnic backgrounds, living in contexts offering unequal opportunities and imposing varied constraints, manage the multiple transition steps to adulthood and give meaning to their choices and decisions. The book is great proof of how our understanding of this process can be improved by listening to their voices. Its tremendously rich portrait of young people's pathways provides keen insight into the intricacies, twists, and turns in the process of becoming adult. I recommend this book to researchers, policymakers, and students interested in gaining a deep insight into what coming of age means in America at the beginning of the 21 st century.

Urban Flow: Bike Messengers and the City. By Jeffrey L. Kidder. Ithaca, N.Y.: Cornell University Press, 2011. Pp. xii+240. \$27.95.

Gregory Smithsimon

Brooklyn College, City University of New York

As Jeffrey Kidder points out in Urban Flow, it's remarkable that bike 